\title{
Rua, espaço de vida pública em disputa
}

Fabio Mariz Gonçalves

Faculdade de Arquitetura e Urbanismo / USP, Doutor em Arquitetura e Urbanismo

fabiomgoncalves@uol.com.br

\section{RESUMO}

Reiteramos o protagonismo das ruas nos Sistemas de Espaços Livres urbanos. As ruas são a própria essência das cidades, os espaços que melhor revelam o grau de desenvolvimento, a história, as conquistas e os problemas das sociedades que nelas habitam. Mesmo sendo espaços tão fundamentais, no século XX, tomadas pelos automóveis, passaram a ser mal compreendidas, transformadas em estradas e mera questão de engenharia de tráfego. Ruas são espaços de permanência, mobilidade, passagem e acesso. Caminhos habitados que exigem pactos negociados diariamente entre os grupos que as utilizam. Não são espaços para o exercício livre da forma ou desejos do arquiteto, nem espaços de fácil delimitação física ou funcional. A perspectiva histórica permite afirmar que a sociedade está caminhando, com disputas e conflitos construindo pactos e espaços melhores. Olhar a história de violência e exclusão no Brasil pode levar ao desânimo, contudo, as cidades não são problemas, são as mais importantes e potentes ferramentas de transformação da sociedade já criadas pela humanidade. O papel dos arquitetos e urbanistas no Brasil deve ser empenhar-se para que as ruas das nossas cidades sejam espaços democráticos, inclusivos, ambientalmente mais resilientes e sustentáveis, verdadeiros instrumentos para a construção de sociedades mais justas e solidárias.

Palavras-chave: rua, cidade, resiliência, democracia.

\begin{abstract}
We reiterate the prominent role of the streets in the urban Free Spaces Systems. The streets are the very essence of cities, the spaces that best reveal the degree of development, history, achievements, and problems of the societies that inhabit them. Despite being such fundamental spaces, in the 20th century, occupied by automobiles, the streets became poorly understood, turned into roads and merely a matter of traffic engineering. Streets are spaces for permanence, mobility, transit, and access, inhabited paths that require pacts negotiated daily between the groups that use them. They are not spaces for the free exercise of the architect's form or desires, nor spaces of easy physical or functional delimitation. The historical perspective allows us to affirm that society is moving forward, with disputes and conflicts building pacts and better spaces. Looking at the history of violence and exclusion in Brazil can lead to discouragement, nevertheless, cities are not problems they are the most important and powerful tools for transforming society already created by humanity. The role of architects and urban planners in Brazil must be to strive for the streets of our cities to be democratic, inclusive, environmentally more resilient and sustainable spaces, real tools for building more just and solidary societies.
\end{abstract}

Keywords: street, city, resilience, democracy. 